\title{
INFLUENCE OF UNDERGROUND STRUCTURES AND INFRASTRUCTURES ON THE GROUNDWATER LEVEL IN THE URBAN AREA OF MILAN, ITALY
}

\author{
L. COLOMBO, P. GATTINONI \& L. SCESI \\ Department of Civil and Environmental Engineering, Politecnico di Milano, Italy.
}

\begin{abstract}
Underground structures and infrastructures (i.e. metro tunnels and stations, deep foundations, etc.) locally affect the groundwater level of the aquifers in urban area, and they can bring about hydrogeological hazards especially in areas also interested by a regional raising trend of the water table. In this paper, the case of Milan (Italy) is discussed by means of the following steps: (1) monitoring data analysis for reconstructing the regional increasing trend of the water table; (2) numerical modelling of the groundwater flow system in steady state; (3) numerical modelling of the interference of underground structures and infrastructures with the aquifer system. More in detail, the study started from a numerical model of the aquifer system of Milan, calibrated in steady state with reference to the maximum water table observed in May 2014. Afterwards, a pilot sub-model of about $9 \mathrm{~km}^{2}$ was refined to simulate the major intersections between the metro lines and the stations. Modelling results pointed out a local increasing of the groundwater levels of about $10-15 \mathrm{~cm}$ over wide areas located nearby the tunnels intersections. Unfortunately, these areas coincide with those areas interested by the highest increase in water table due to the regional trend. Therefore, even if the local changes are quite low, they can negatively affect underground structures and buildings because of the superimposition of effects.

Keywords: groundwater management, Italy, numerical modelling, underground infrastructures, urban area.
\end{abstract}

\section{INTRODUCTION}

Underground structures and infrastructures (i.e. metro tunnels and stations, deep foundations, etc.) locally affect the groundwater level of the aquifers in urban area, and they can bring about hydrogeological hazards especially in areas also interested by a regional raising trend of the water table. Actually, in the last decades, an increasing trend in groundwater level due to the deindustrialization process was observed in urban aquifers all around the world: from Buonos Aires in Southern America to New Haven in Northern America, from Cairo City in Africa to Bangkok and Tokyo in Asia. Many European cities are affected by the same problem: Barcellona, Birmingham, Nottingham, Liverpool, London, Paris, Berlin and Milan [1-3]. The water table rising in these urban areas was the result of a deindustrialisation process, with the related decrease in groundwater pumping, which was not properly managed, and it therefore caused serious damages to underground structures and infrastructures.

In this paper, the case of Milan (Italy) is discussed. First, the hydrogeological setting of the area is described and the monitoring data are analysed to reconstruct the regional increasing trend of the water table (Fig. 1). Afterwards, a 3D numerical model of the groundwater flow system is described. More in detail, the study starts from a numerical model of the whole aquifer system of Milan, based on the data arising from previous studies. This model considered the two 
main aquifers of Milan and it was calibrated in steady state with reference to the maximum water table observed in May 2014. On this basis, a pilot sub-model of about $9 \mathrm{~km}^{2}$ is refined to simulate the major intersections between the metro lines and the stations, which geometry and altimetry were reconstructed based on the available data. Finally, the interference of underground structures and infrastructures with the aquifer system is simulated and the results are discussed.

\section{THE CASE OF MILAN (ITALY)}

The city of Milan (Lombardy, Northern Italy) lies on the Northern margin of the alluvial plain of the Po River (Fig. 1). The hydrogeological structure of the area has been the object of a number of investigations $[4,5]$.

The water-bearing alluvial deposits are more than $250 \mathrm{~m}$ thick and can be subdivided into four large-scale geological units denoted (from the youngest to the oldest) by A, B, C and D Aquifer Groups. These depositional cycles are separated by clayey deposits, which form

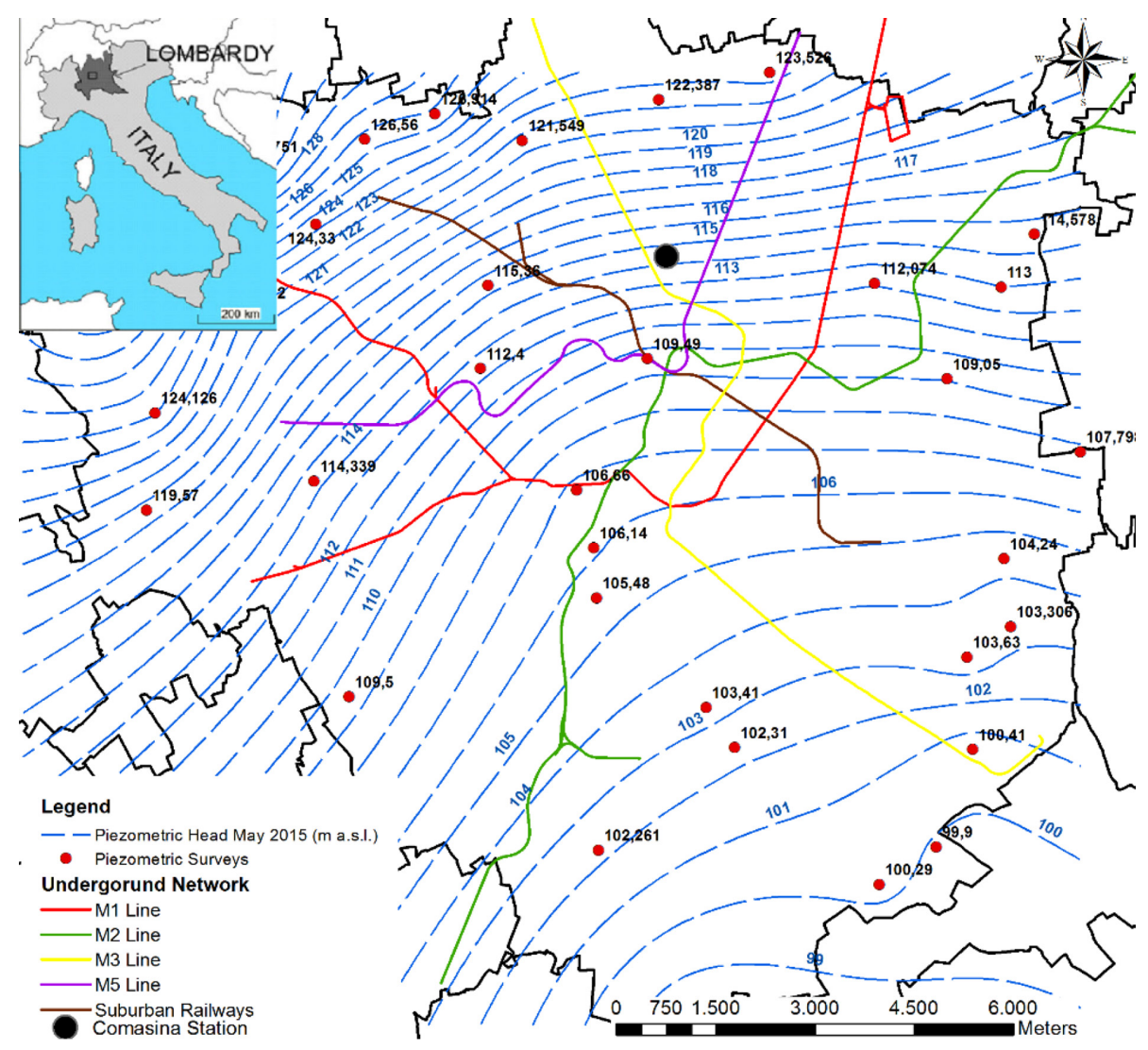

Figure 1: Location (in the upper left corner) and piezometrical map of the study area: the blue lines represent the groundwater table ( $\mathrm{m}$ a.s.1.) in 2015. The underground railway network of Milan is also shown: the colour continuous lines represent the existing metro lines (red, green, yellow and purple) and the suburban railway (in brown); the grey line is the municipality border. The circle shows the location of the monitoring well (in black the Comasina station, for which the piezometrical trend is shown in Fig. 3). 


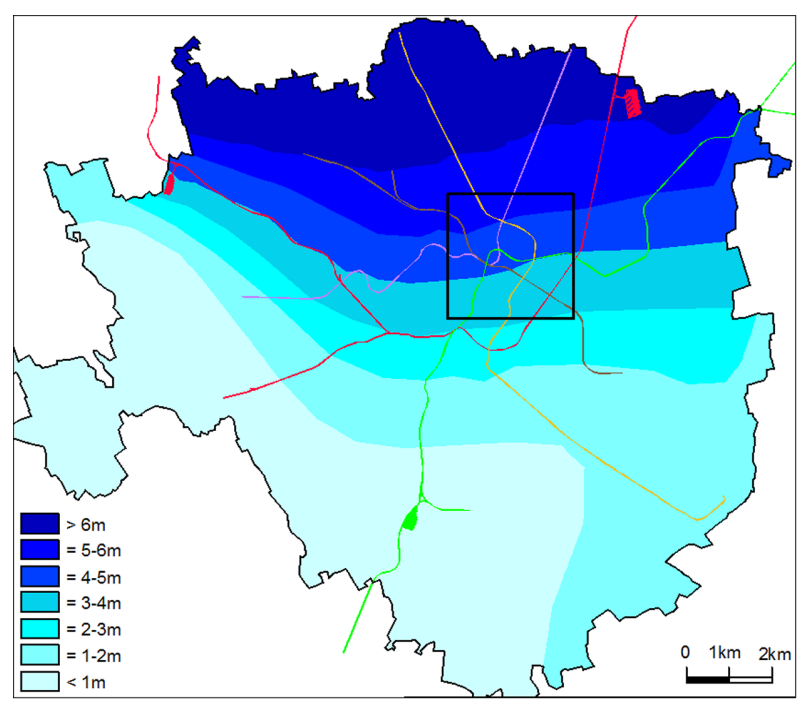

Figure 2: Groundwater rising (in m) from 2000 and 2014. The colour lines represent the urban network (see Fig. 1 for reference). The black box indicates the domain used in the numerical flow model.

aquitards. More in detail, the aquifers traditionally exploited in the study area (A and B) consist of a hydrogeological system of unconfined and semi-confined aquifers within a system of very heterogeneous layers.

The groundwater flow occurs form NNW to SSE (Fig. 1) and the water table has shown a rising trend since '90s (Figs 2 and 3): the rise get $6 \mathrm{~m}$ in the northern area of Milan in the last decade (Fig. 2). This rising trend interferes with the structures and infrastructures which have been built in the underground of Milan from ' 60 s to ' 80 s, bringing about both management troubles for the railway urban system and safety issues for the structures. For instance, the metro line green and yellow, which were design to function in dry conditions, now lie below the water table (Fig. 4), involving important waterproofing works. If the groundwater trend will go on with the same rate, in the next 10 years static problems will be triggered.

\section{GROUNDWATER FLOW MODELLING}

\subsection{Hydrogeological conceptual model}

For the hydrogeological characterization of the study area, the data-base developed for the Italian geologic cartography project was used [5] and a proper 3D model of the aquifer was developed [6]. In particular, more than 4,000 log-stratigraphies were analysed, arising from wells and bore-holes which interest mainly the Aquifer Groups A and B (the first 100-150 m of depth). Aquifer Group A is mainly constituted by gravels with sandy layers having a hydraulic conductivity higher than $10^{-3} \mathrm{~m} / \mathrm{s}$, whereas Aquifer Group B is mainly constituted by sands and gravels with silty and clayey layers, with an equivalent hydraulic conductivity of about $10^{-4} \mathrm{~m} / \mathrm{s}$. The bottom surfaces of Aquifer Group A (Fig. 5), which is directly interested by the interaction with underground structures and infrastructures has a dip direction 


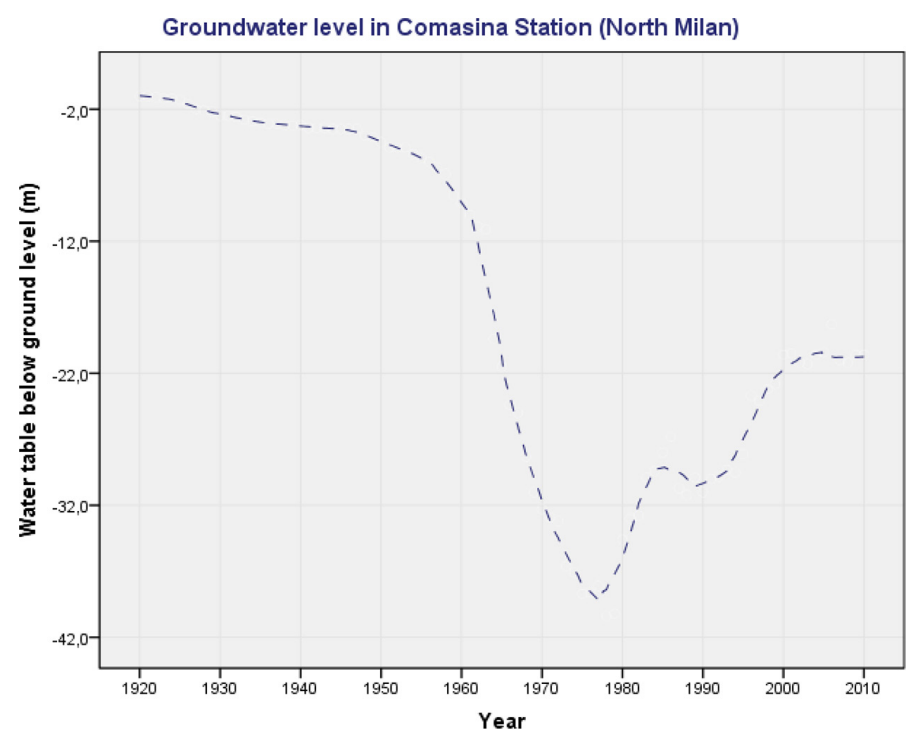

Figure 3: Monitoring data in the last century of the water table depth below ground level (see Fig. 1 for the location of the monitoring well).

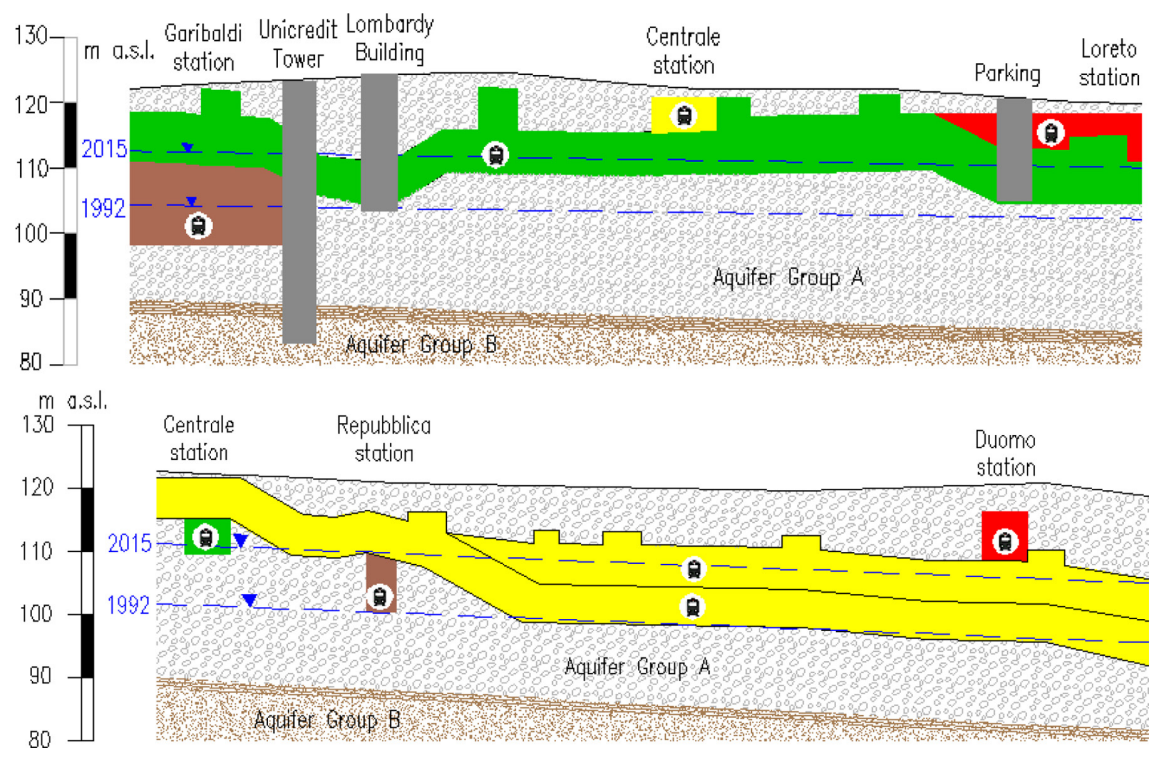

Figure 4: Schematic cross-sections along the green metro line (above) and yellow line (below), showing the hydrogeological setting of the aquifers and rising water table (in blue). The brown Suburban Railway and the red metro line are also shown.

towards S-SE with an altitude equal to 100 (in the northern area of Milan) and $60 \mathrm{~m}$ a.s.l. (in the southern area). The bottom surface of the Aquifer Group B has the same dip direction, with an altitude equal to $50 \mathrm{~m}$ a.s.l. (to the North) and $-10 \mathrm{~m}$ a.s.l. (to the South). The aquitard separating the two aquifers is present only in the Southern zone; its thickness increases 


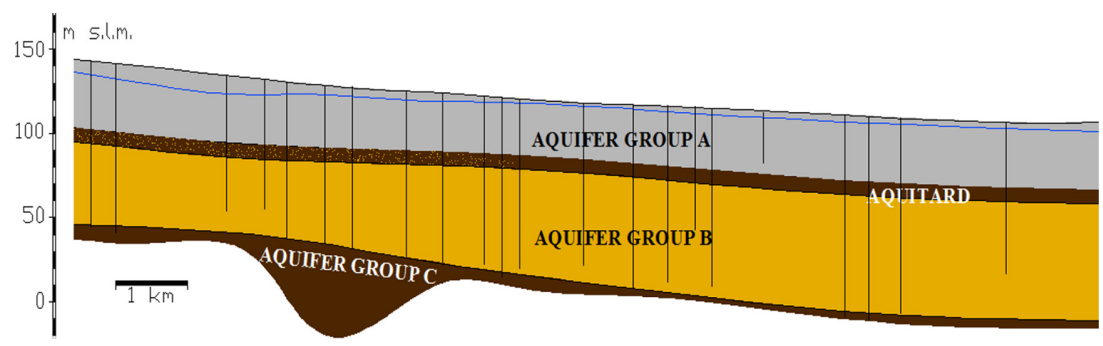

Figure 5: Schematic N-S cross-section of the study area. The blue line represents the water table, whereas the black lines are the wells used for the hydrogeological interpretation.

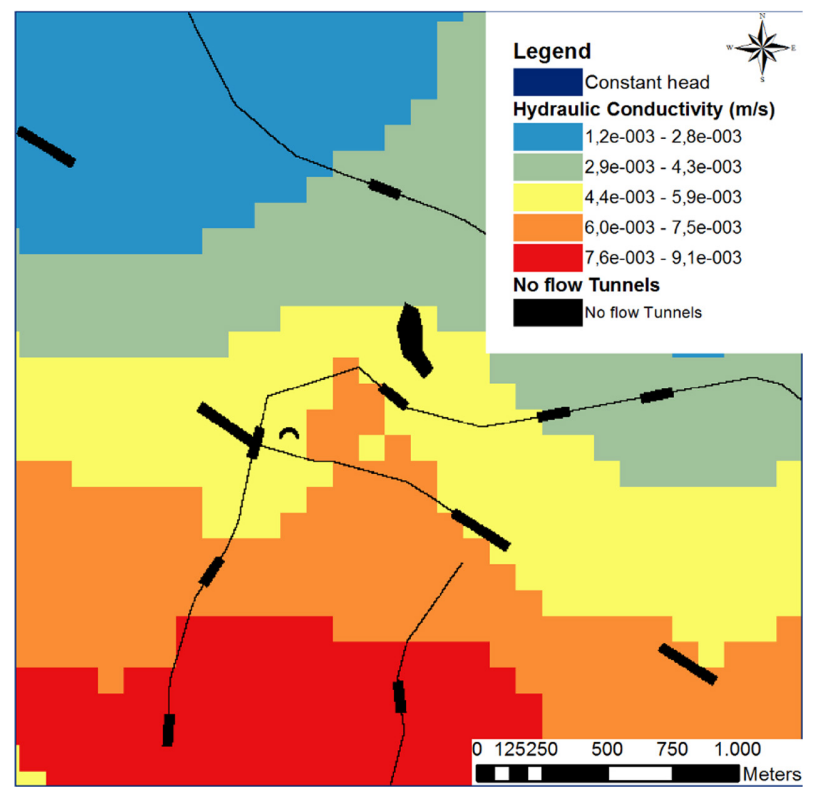

Figure 6: Hydraulic conductivity distribution in Aquifer Group A.

towards S-E, where it reaches $10-12 \mathrm{~m}$ thick with the consequent complete separation of the two aquifers.

\subsection{D numerical model}

The numerical model in a pilot area of $9 \mathrm{~km}^{2}$ (Fig. 2) has been implemented starting from a regional groundwater flow model of the whole alluvial plain of the Milan District. The regional model was implemented with the finite-difference code MODFLOW-2000 [7], and it was calibrated in steady state based on the monitoring data of March 2014. The obtained results were good and representative of the regional groundwater flow. In the present study, this large-scale model was used by refining the mesh $(5 \mathrm{~m} \times 5 \mathrm{~m})$ to introduce the proper boundary conditions in the detailed model. As results, constant head boundary conditions are applied on the Northern (112 m a.s.l.) and Southern (104 m a.s.l.) border of the domain. The 

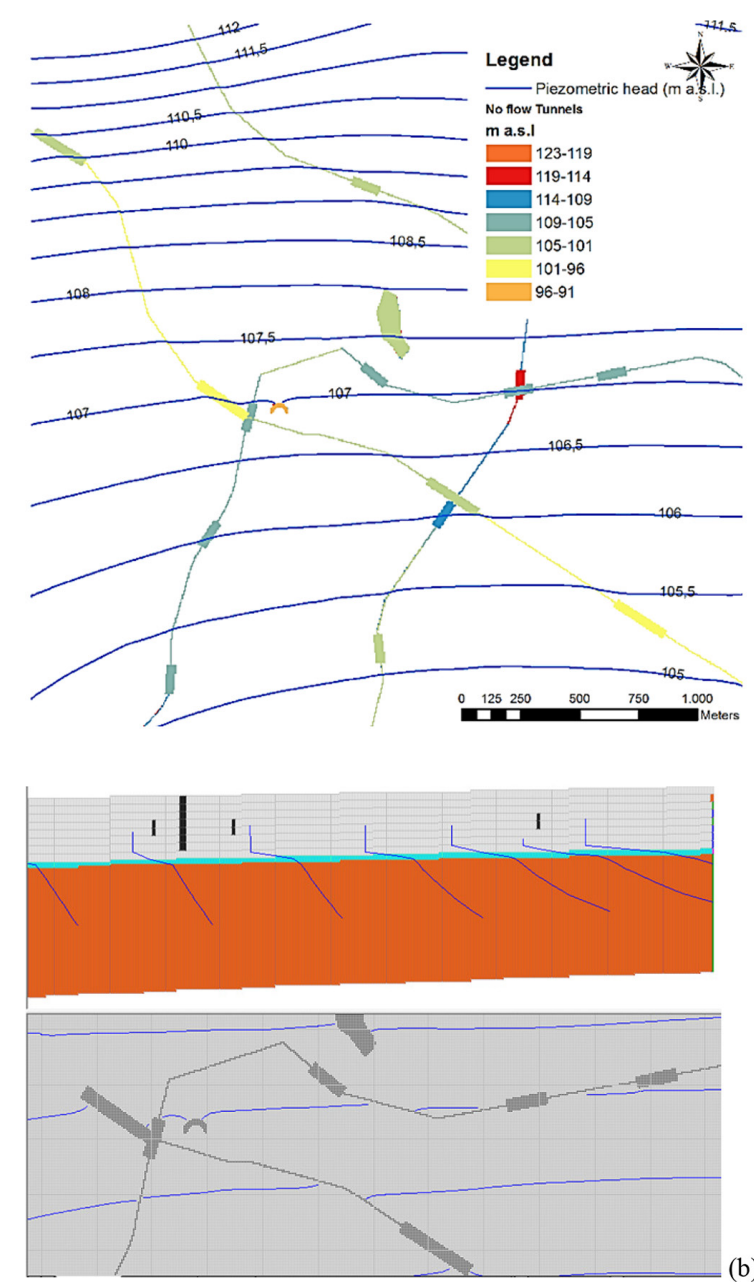

(a)

(b)

Figure 7: (a) Water table map (in m a.s.l.) simulated by the numerical model. Coloured cells are tunnels and stations in the different at the different depths; (b) vertical discretization of the model (Aquifer Group A in white, Aquifer Group B in orange, and aquitard in light blue), with a zoom of the results nearby the Garibaldi intersection.

recharge is applied considering the use of soil as total urban, and therefore the value is very low $(30 \mathrm{~cm} / \mathrm{y})$.

Moreover, the vertical discretisation was refined (reaching a layer thickness of $2.5 \mathrm{~m}$ ) to draw tunnels, stations and foundations at the proper depth in the shallow aquifer. The hydraulic conductivity ranges from 1.5 to $6.7 \mathrm{E} 10^{-3} \mathrm{~m} / \mathrm{s}$ in the first 8 layers representing the Aquifer Group A (Fig. 6), whereas in the deeper layer of the Aquifer Group B they range from 1.3 to $3.5 \mathrm{E} 10^{-3} \mathrm{~m} / \mathrm{s}$.

Tunnels, metro stations and foundation are simulated as impermeable elements within the numerical model. The modelling results show a slight influence of these impermeable elements on the water table, which is affected by local deformations, especially nearby the largest stations and the tunnel intersections (Fig. 7). 


\section{RESULTS AND DISCUSSION}

Modelling results show local deformations of the water table nearby the underground structures and infrastructures (Fig. 7). These deformations consist in a rise of the groundwater located upstream the impermeable elements (with respect to the water flow direction), whereas a groundwater drawdown is located downstream. Rise and drawdown reach maximum values of about $\pm 15 \mathrm{~cm}$ where the underground structures have a major development in a direction orthogonal to the groundwater flow, where the metro lines are deeper. This is well shown in Fig. 8a, where near the yellow line, having a direction approximately orthogonal to the groundwater flow, the water table change reaches its maximum value, whereas along the green line the changes are low because the tunnel is not so deep.

Structures and infrastructures, acting as impermeable elements, also involve a change in the water flow path: the flow direction locally assumes a significant vertical component, which is directed downwards in the upstream zone of the structures, whereas the flow path has an upwards component in the downstream zone (Fig. 8b). This variation in the flow path, especially the upwards component, may have negative consequences because of the uplift thrust that it brings about on structures.

Moreover, the flow velocity can be created for the superposition of effects (pumping stations, underground infrastructures) and this phenomena can be dangerous for water quality [8] but also for suffosion [9]. In this paper, in particularily. In this paper, in particular, the

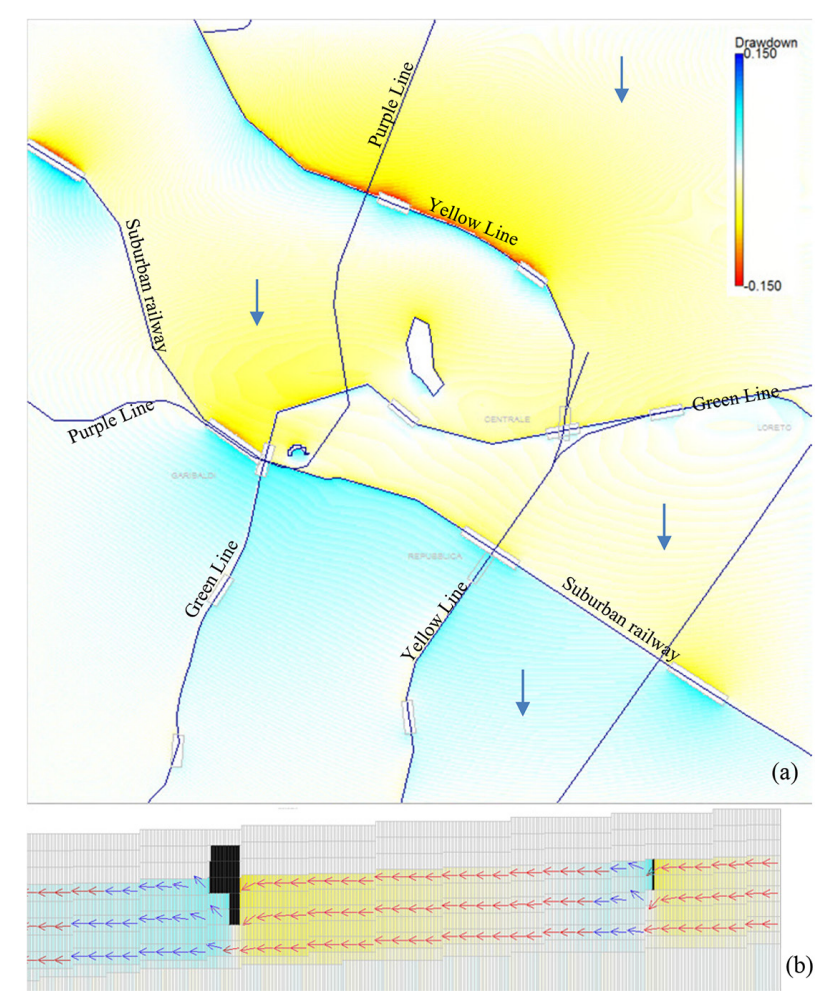

Figure 8: Water table changes (in $\mathrm{m}$ ) simulated by the numerical model: (a) plan view of the whole domain; (b) N-S cross section in the intersection node of Garibaldi. Black cells are tunnels and stations. Arrows show the flow direction. 

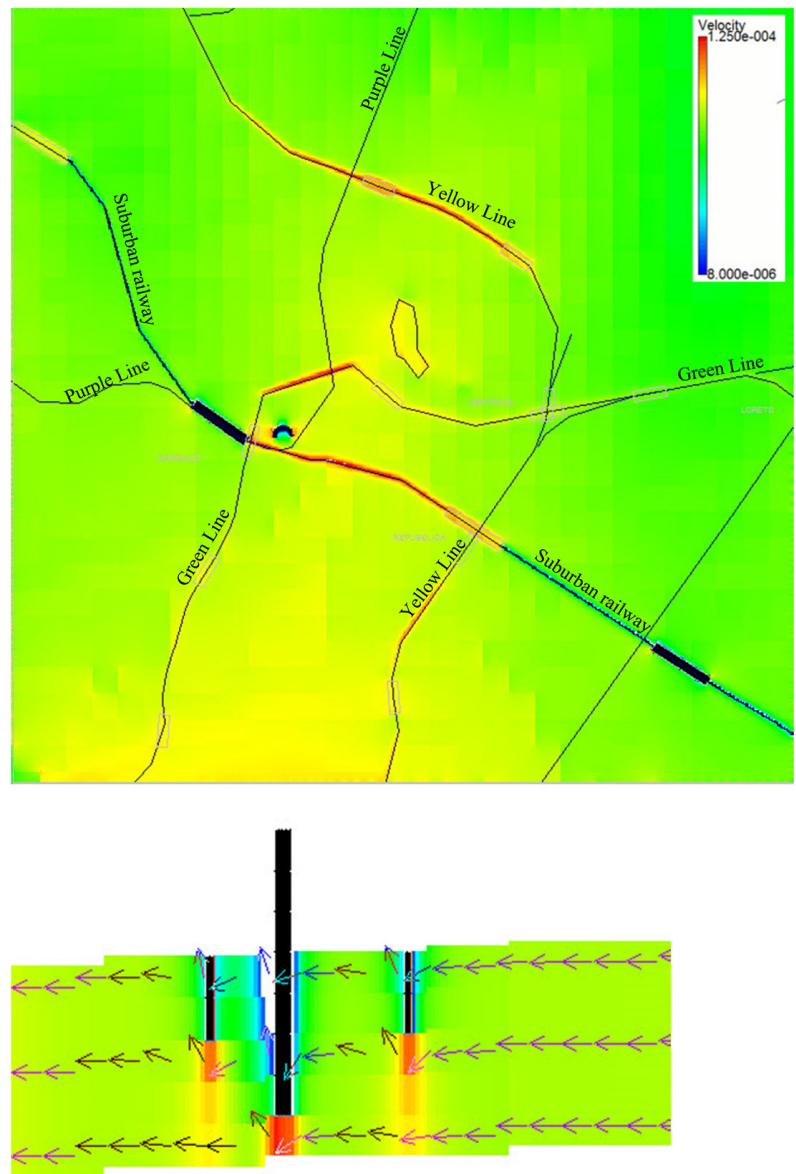

Figure 9: Water flow velocity (in $\mathrm{m} / \mathrm{s}$ ) simulated by the numerical model: (a) plan view of the whole domain; (b) N-S cross section in the intersection node of Garibaldi.

presence of underground infrastructures below the groundwater table affects the flow velocity (Fig. 9a). In particular, at the same altitude of the impermeable elements the flow slows down (both upstream and downstream), whereas in depth (below the impermeable elements) the increase in flow velocity reaches one order of magnitude (Fig. 9b). This increase in flow velocity should be verified in borehole, for istance through the use flow meter tests [10]. Actually. such an increase may bring about erosive phenomena, especially for the finest soil particles, which in the long term can lead to settlements and instabilities of the structures [11].

\section{CONCLUSIONS}

Modelling results pointed out a local increasing of the groundwater levels of about 10-15 cm over wide areas located nearby the tunnels intersections. Unfortunately, these areas coincide with those areas interested by the highest increase in water table due to the regional trend. Therefore, even if the local changes are quite low, they can negatively affect underground structures and buildings because of the superimposition of effects. 
Actually, the upward trend of the water table may continue in the next years and reach levels similar to those observed in the " 50 s. Such a rise will be not suitable for the anthropic underground world of Milan, as the structures were not design for these values of the water pressure. Therefore, it is very evident the need of in depth studies aimed at forecasting the water table trend, as well as at evaluating the efficacy of the different mitigation strategies, from a proper management of the recharge practice, to a different regulation of the hydraulic network.

\section{REFERENCES}

[1] Dean, J. \& Sholley M., Groundwater basin recovery in urban areas and implications for engineering projects, IAEG, The Geological Society of London: London, 2006.

[2] Lamè, A., Modélisation hydrogèologique des aquifers de Paris et impacts des aménagements du sous-sol sur les écoulements souterains, Earth Science, Ecole Nationale Supériore des Mines de Paris, France.

[3] Wilkinson, B., Rising groundwater levels in London and possible effects on engineering structures. Memories of the 18th Congress of the International Association of Hydrogeologists, Cambridge, pp. 145-156.

[4] Regione Lombardia - ENI, Geologia degli Acquiferi Padani Della Regione Lombardia, ed. C. Carcano \& A. Piccin, Selca: Firenze, 2002.

[5] Servizio Geologico d'Italia, Carta Geologica d'Italia - Milano Foglio 118, 2002.

[6] Forcella, V., Francani, V., Gattinoni, P. \& Scesi, S., A 3d model of the aquifer of Milan (Northern Italy), 14th GeoConference on Science and Technologies in Geology, Exploration and Mining, Bulgaria, Vol. 2, pp. 3-10, 2014, ISBN 978-619-7105-08-7, ISSN 1314-2704.

[7] Harbaugh, A.W., Banta, E.R., Hill, M.C. \& McDonald, M.G., The U.S. Geological Survey modular ground-water model - User guide to modularization concepts and the groundwater flow process, open-file report 00-92, 2000, United States Geological Survey, Boulder, Co, 121p.

[8] Alberti, L, Colombo, L. \& Francani, V., The groundwater flow velocity distribution in the urban areas: a case study. Italian Journal of Engineering Geology and Environment, 14(2), pp. 17-26, 2015.

[9] Colombo, L., Francani, V. \& Gattinoni, P., Suffosion hazard for building and infrastructure in the high Lombardy plain (Northern Italy). 14th GeoConference on Science and Technologies in Geology, Exploration and Mining, Bulgaria, Vol. 2, pp. 327-324, 2014, ISBN 978-619-7105-08-7, ISSN 1314-2704.

[10] Francani, V., Gattinoni, P., Schöttler, M., Mottini, S., Rigamonti D.S. \& Vitiello M., Application of borehole flow measurements to characterize hydraulic heterogeneities and their impact on the local groundwater flow network, Italian Journal of Engineering Geology and Environment, 1, pp. 5-14, 2015.

[11] Lorenzo, C., Consonni, M., Colombo, L. \& Gattinoni, P., Stability problem for infrastructure in the areas interested by cavities in the pleistocenes sediments in the Lombardy plain (Italy). memorie descrittive della carta geologica d'italia, XCIX, pp. 315-326, 2015. 